\title{
The Rieti Land Reclamation Authority relevance in the management of surface waters for the irrigation purposes of the Rieti Plain (Central Italy)
}

\section{II ruolo del Consorzio della Bonifica Reatina nella gestione delle acque superficiali per l'irrigazione nella Piana Reatina (Italia Centrale)}

\author{
Lucio Martarelli, Marcello Iacuitto, Vincenzo Gregori, Riccardo Massimiliano Menotti, Marco Petitta, Anna Rosa Scalise
}

Riassunto: La Piana Reatina è circondata da rilievi calcareomarnosi (Monti Reatini e Monti Sabini) e rappresenta un bacino alluvionale e fluvio-lacustre intra-appenninico plio-quaternario formato in seguito ad attività tettonica estensionale polifase. Questo territorio è ricco di risorse idriche (fiumi Velino e Turano; numerose sorgenti; laghi Lungo e Ripasottile, relitti dell'antico Lacus Velinus). Gli acquiferi presenti nei rilievi hanno spesso continuità idraulica con le acque sotterrane della Piana Reatina (soggiacenti a circa 1-4 m dal piano campagna), che hanno direzioni di deflusso sotterraneo generalmente convergenti dai rilievi verso il settore centrale dei laghi. Inoltre, sono stati evidenziati scambi idraulici variabili nel tempo e nello spazio tra le acque sotterranee e quelle superficiali, di particolare interesse per la distribuzione della risorsa idrica sotterranea.

Parole chiave: Consorzio della Bonifica Reatina, gestione acque superficiali, irrigazione, idrogeologia, Piana Reatina.

Keywords: Rieti Land Reclamation Authority, surface water management, irrigation, hydrogeology, Rieti Plain.

\author{
Lucio MARTARELLI 莑”* \\ Geological Survey of Italy \\ Italian National Institute for Environmental Protection and Research \\ via Vitaliano Brancati 48, 00144 Rome, Italy \\ Tel. +39.06.50074364. \\ lucio.martarelli@isprambiente.it
}

\section{Marcello IACUITTO, Vincenzo GREGORI \\ Rieti Land Reclamation Authority \\ via delle Orchidee 20, 02100 Rieti, Italy.}

Riccardo Massimiliano MENOTTI

IFAC-CNR

via Madonna del Piano 10, 50019 Sesto Fiorentino, Florence, Italy.

\section{Marco PETITTA}

Earth Science Department - Sapienza University of Rome p.le Aldo Moro 5, 00185 Rome, Italy

Anna Rosa SCALISE

Geological Survey of Italy

Italian National Institute for Environmental Protection and Research via Vitaliano Brancati 48, 00144 Rome, Italy

Ricevuto: 19 maggio 2016 / Accettato: 11 agosto 2016 Pubblicato online: 16 settembre 2016

This is an open access article under the CC BY-NC-ND license: http://creativecommons.org/licenses/by-nc-nd/4.0/

(C) Associazione Acque Sotterranee 2016
Il Consorzio della Bonifica Reatina, istituito nel 1929 con Regio Decreto N. 34171-3835, è il risultato dell'unione di otto precedenti consorzi, istituiti verso la fine del 1800, e contribuisce al mantenimento delle attività di bonifica nella Piana Reatina, iniziate con la costruzione dei bacini idrici artificiali del Salto e del Turano lungo due degli affluenti di sinistra del Fiume Velino. Gli obiettivi legati all'attività idroelettrica sono spesso stati in contrasto con quelli per la bonifica e la mitigazione delle esondazioni nella piana.

Il Consorzio della Bonifica Reatina ha attuato nel tempo il Piano Generale di Bonifica con la messa in opera di idrovore, canali di collegamento e drenaggio, sistemazioni idraulico-forestali, strade rurali, traverse fluviali mobili lungo il Fiume Velino e canali di irrigazione. Le attività di irrigazione, autorizzate alla derivazione di $5 \mathrm{~m}^{3} / \mathrm{s}$ dal Fiume Velino, sono state realizzate in 194000 ettari nel territorio di 42 Comuni della Provincia di Rieti. Il Consorzio della Bonifica Reatina contribuisce alla protezione ed al monitoraggio delle acque d'irrigazione ed ambientale e geologico-idraulico in generale.

Abstract: The Rieti Plain is crowned by calcareous-marly reliefs (Rieti and Sabini Mountains) and represents an intra-Apennine PlioQuaternary alluvial and fluvial-lacustrine basin formed after multistage extensional tectonic processes. This territory presents huge amounts of water resources (Velino and Turano rivers; several springs; Lungo and Ripasottile lakes, relics of ancient Lacus Velinus). The aquifers occurring in the reliefs often have bydraulic continuity with the Rieti plain groundwater (detected at about 1-4 m below ground surface), which has general flow directions converging from the reliefs to the lake sector. Hydraulic exchanges between groundwater and surface waters are variable in space and time and play a relevant role for groundwater resource distribution. The Rieti Land Reclamation Authority was instituted in 1929 by Royal Decree N. 34171-3835, and integrates eight former authorities, dating the end of 1800 s. It contributes to maintain the reclamation actions in the Rieti Plain, which started with the realization of the Salto and Turano artificial reservoirs, along two left tributaries of Velino River. The hydroelectric energy production purposes struggle with the reclamation and flood mitigation activities in the plain. The Land Reclamation Authority actuated the Integrated Reclamation General Project through the realization of pumping stations, connection and drainage canals, forestry-hydraulic works, rural roads, movable dams along Velino River and irrigation ditches. The irrigation activities, granted by the derivation of $5 \mathrm{~m}^{3} / \mathrm{s}$ from the Velino River, are carried out through 194,000 hectares within the territory of 42 municipalities of the Rieti Province.

The Rieti Land Reclamation Authority contributes to the irrigation needs and to the environmental and hydrogeological protection and monitoring. 


\section{Introduction}

The Consortium for Rieti Land Reclamation is located in the Rieti Province (Latium, Central Italy) and is mainly placed in the Rieti Plain, which is crowned by the Rieti Mountains (the highest elevation is 2,217 $\mathrm{m}$ a.s.l., Terminillo Mount) and the Sabini Mountains (Fig. 1). It represents an intra-Apennine basin formed after intense multistage extensional tectonic processes. It is composed of Plio-Quaternary alluvial and fluvial-lacustrine sediments and is bordered by reliefs formed of calcareous-marly and detritic deposits.

The main feature of this territory is the huge amounts of water resources, mainly represented by Velino and Turano rivers, several springs and Lungo and Ripasottile lakes, formed after the reclamation (from III century B.C. to nowadays) of the ancient Lacus Velinus.

The aquifers occurring in the reliefs and the groundwater in the Rieti plain often have hydraulic connections, also through the detritic terrains, and feed springs along the plain border. Hydraulic exchanges between groundwater and surface waters are variable in space and time and play a relevant role in groundwater resource distribution.

The main purpose of this paper is to give information on the key management and maintenance activities carried on

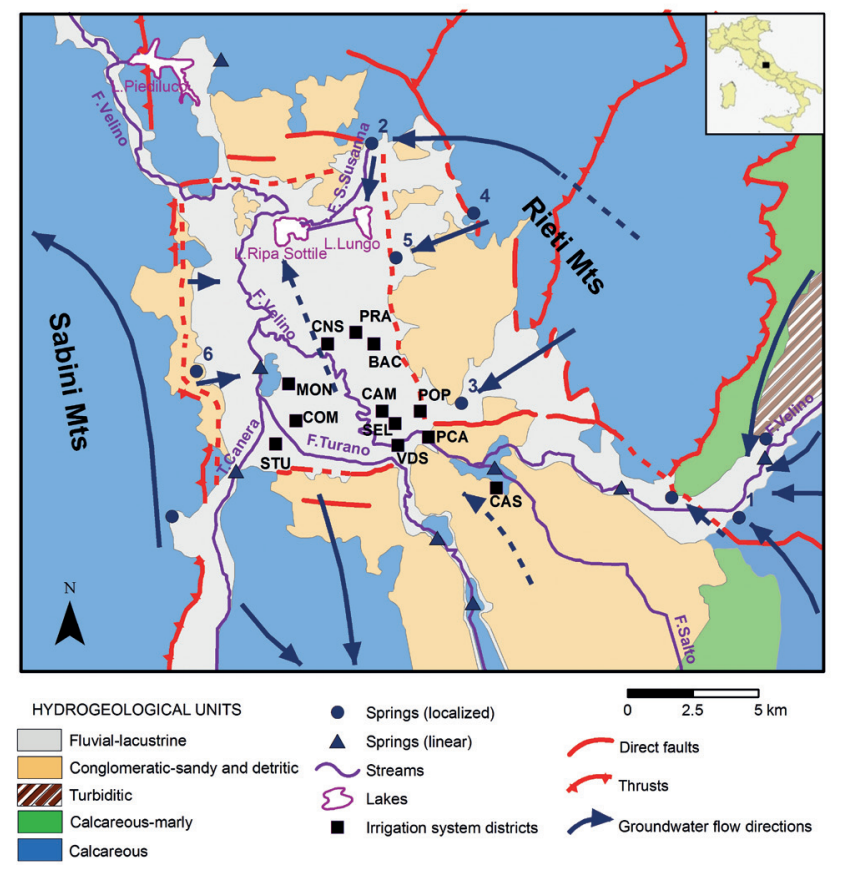

Fig. 1 - Hydrogeological sketch map of the Rieti Plain (modified from Falcetti et al. 2015). Main springs: 1) Peschiera; 2) S. Susanna; 3) Cantaro; 4) S. Liberato; 5) Vicenna Riara; 6) Onnina. Irrigation system districts: $P C A=$ Ponte Cavallotti, VDS $=$ Voto dei Santi, $P O P=$ Porrara-Padule, $C A M=$ Camporeatino, $S E L=S$. Eleuterio, CNS $=$ Chiesa Nuova-Saletto, BAC = Basso Cottano, $P R A=$ Pratolungo, COM = Comunali, $S T U=$ Sinistra Turano, $M O N=$ Montisola,$C A S=$ Casette

Fig. 1 - Schema idrogeologico della Piana Reatina (modificato da Falcetti et al. 2015). Sorgenti principali: 1) Peschiera; 2) S. Susanna; 3) Cantaro; 4) S. Liberato; 5) Vicenna Riara; 6) Onnina. Distretti del sistema di irrigazione: PCA $=$ Ponte Cavallotti, VDS $=$ Voto dei Santi, POP $=$ Porrara-Padule, CAM = Camporeatino, $\mathrm{SEL}=\mathrm{S}$. Eleuterio, $\mathrm{CNS}=$ Chiesa Nuova-Saletto, $\mathrm{BAC}=\mathrm{Basso}$ Cottano, $\mathrm{PRA}=$ Pratolungo, $\mathrm{COM}=$ Comunali, $\mathrm{STU}=$ Sinistra Turano, $\mathrm{MON}$ $=$ Montisola, CAS $=$ Casette. throughout the Rieti Plain, representing a reclamation land featured by complex hydraulic and hydrogeological settings.

\section{Materials and Methods Hydrogeological features of the Rieti Plain}

The hydrogeological asset of the Rieti Plain is deeply reliant by the regional hydrodynamics. Four major outflows from the basal aquifer occur in it (Fig. 1), each one fed by different calcareous hydrostructures within the Rieti and Sabini Mts (marine basin Umbro-Sabina Sequence) and the Giano-NuriaVelino Mts (marine carbonate shelf): the S. Susanna Springs at NE, located at the contact between the Rieti Mts slope and the Rieti Plain $\left(5.5 \mathrm{~m}^{3} / \mathrm{s}\right)$; the Peschiera Springs along with many other springs (total discharge about $30 \mathrm{~m}^{3} / \mathrm{s}$ ) located in the S. Vittorino Plain at E; the Le Capore Springs (average discharge $5 \mathrm{~m}^{3} / \mathrm{s}$ ) at $\mathrm{S}$, in the Farfa Creek valley; the linear spring of the Montoro-Stifone gorges at NW (about $15 \mathrm{~m}^{3} / \mathrm{s}$ ).

The Rieti Mts hydrostructure feeds springs located at the E margin of the Rieti Plain (e.g., Manfredini 1972; Boni et al. 1995; Martarelli et al. 2008). Among these, other than the cited S. Susanna Springs (383 m a.s.l.), the S. Liberato $\left(0.1 \mathrm{~m}^{3} / \mathrm{s}\right.$, $580 \mathrm{~m}$ a.s.1.) and Vicenna Riara $\left(0.07 \mathrm{~m}^{3} / \mathrm{s}, 374 \mathrm{~m}\right.$ a.s.l. $)$ springs, at the base of the western slope of the Terminillo $\mathrm{Mt}$, and the Cantaro Springs $\left(0.5 \mathrm{~m}^{3} / \mathrm{s}, 400 \mathrm{~m}\right.$ a.s.l.; partly used by wells for the water supply of the Rieti town), in the southern part of the Rieti Mts, are included. Other linear springs occur along the Salto and Turano rivers between the respective dams and the Rieti Plain (about $0.5 \mathrm{~m}^{3} / \mathrm{s}$ ) and are fed by Umbro-Sabina Series calcareous-marly substrate, cropping out in the valley floor beneath the Plio-Pleistocene deposits (e.g., Boni et al. 1995).

A phreatic groundwater body having hydraulic exchanges variable in time and space with streamwaters is hosted within the Rieti Plain, even if it is composed of scarcely permeable recent fluvial-lacustrine deposits. Its depth to groundwater is 1-4 $\mathrm{m}$ from ground level in the central sector of the plain. Groundwater flow directions are generally from SSE to NNW (average hydraulic gradient is $0.2 \%$; e.g., Martarelli et al. 2008). More in detail, in the NE sector of the plain, groundwater flow is from NNE to SSW in the northernmost part and from ENE to WSW moving to south (Poggio Bustone and S. Liberato conoids) and it is addressed to the Lungo and Ripasottile lakes. Whereas, in the SW and W sectors, groundwater flow directions are generally from $\mathrm{W}$ to $\mathrm{E}$ and the Velino River, perched on the plain, releases streamwater to the phreatic groundwater body. On the contrary, Velino River drains groundwater at north (e.g., Martarelli et al. 2008).

Although it is well known that the aquifer system of the Rieti Plain is very complicated (e.g., Manfredini 1972; Boni et al. 1995), it was here possible to make some considerations, even if based on strong simplifications, about the hydrogeological budget of the plain. Therefore, assuming the Rieti Plain (about $90 \mathrm{~km} 2$ ) as a water budget unit and taking into account the information from the meteo-climatic stations at Rieti, Contigliano and Poggio Mirteto (Annali Idrologici 1921-2012) and the runoff data available from literature (e.g., Annali Idrologici 1921-2012, Boni et al. 
1995, Di Domenicantonio 2000, Martarelli et al. 2008), the most relevant elements to the hydrogeological budget were estimated (Tab. 1). At this purpose, it must be taken into consideration that both waters pumped from the Ripasottile Lake $\left(5 \mathrm{~m}^{3} / \mathrm{s}\right)$ for reclamation activity and those diverted for irrigation from the Velino River at Voto dei Santi and Ponte Cavallotti $\left(5 \mathrm{~m}^{3} / \mathrm{s}\right)$ can be omitted from the budget calculation, since they are released downhill in the plain area, and that the private well withdrawals of water for irrigation are not likely significant, also considering that diverted waters partly reinfiltrate after irrigation.

As a whole, the relatively scarce amount of estimated effective infiltration (Tab. 1) is reliable, probably due to the low permeability of the Rieti Plain deposits, and is as well compatible with the proposed groundwater flow of the Rieti Plain hydrostructure (about $1 \mathrm{~m}^{3} / \mathrm{s}$, corresponding to 350 mm/year; e.g., Manfredini 1972, Di Domenicantonio 2000).

Tab. 1 - Aspects of hydrogeological budget in the Rieti Plain hydrostructure. Tab. 1 - Elementi del bilancio idrogeologico nell'idrostruttura della Piana Reatina.

\begin{tabular}{|c|c|c|}
\hline & \multirow[b]{2}{*}{$\mathrm{m}^{3} / \mathrm{s}$} & \multirow[b]{2}{*}{$\mathrm{mm} /$ year } \\
\hline & & \\
\hline Mean annual rainfall $(\mathbf{P})$ & 3.1 & 1100 \\
\hline $\begin{array}{l}\text { Potential evapotranspiration }{ }^{[1]} \\
\text { (Turc method) }\end{array}$ & 1.8 & 600 \\
\hline \multirow{3}{*}{$\begin{array}{l}\text { Runoff balance (R) } \\
\text { (difference between surface } \\
\text { runoff OUT and IN of the } \\
\text { Rieti Plain system) }\end{array}$} & $\begin{array}{c}\text { OUT } \\
\text { Le Marmore }{ }^{[2]} 47 \div 50\end{array}$ & \\
\hline & 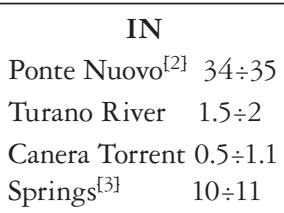 & \\
\hline & $\begin{array}{l}\text { Difference OUT-IN } \\
0.9 \div 1.0\end{array}$ & $300 \div 350$ \\
\hline $\begin{array}{l}\text { Net effective infiltration } \\
\text { (P-ET-R) }\end{array}$ & $0.4 \div 0.6$ & $150 \div 200$ \\
\hline
\end{tabular}

${ }^{[1]}$ Mean annual temperature $13^{\circ} \mathrm{C}$;

[2] Velino River;

${ }^{[3]}$ e.g., S. Susanna, Canapine, Vicenna Riara, S. Liberato, Cantaro

\section{The Integrated Reclamation General Project in the Rieti Plain: history and activities}

The Rieti Land Reclamation Authority, instituted in 1929 by Royal Decree N.34171-3835 and integrating eight former authorities dating to the end of 1800 s, is charged to realize the Reclamation General Project by the finalization of hydraulic actions aimed at irrigation and prevention of ordinary and extraordinary floods in the Rieti Plain (e.g., Lorenzetti 1989; Marinelli 2010; Iacuitto 2011).

These actions have mainly consisted in: (i) realization of the Salto and Turano artificial river basins; (ii) increasing of the Velino River discharge to the Marmore Falls; (iii) realization of two upstream connection canals in both right and left banks of Velino River; (iv) arrangement of Maraone Creek and of a connection canal between Lungo and Ripasottile lakes (Vergara Canal); (v) realization of pumping stations at Ripasottile and Reopasto; (vi) forestry-hydraulic works through the hydrographic basins of Canera Torrent and Ariana Creek (SW and SE from Rieti Plain, respectively) and hydraulic protection works of Nera River. The Gronda Est connection canal completed the reclamation works for the hydraulic protection of the $\mathrm{N}$ sector of the Rieti Town.

From 1934 to 1939 , before and during the realization of the two artificial river basins, the S. Susanna Canal (length 9 $\mathrm{km}$; width $20 \mathrm{~m}$; max discharge $22 \mathrm{~m}^{3} / \mathrm{s}$ ) was dug in order to collect the upstream waters in the right bank of Velino River (delivery to Velino River of S. Susanna Spring and Gronda Nord waters; Fig. 2).

The Turano and Salto artificial reservoir building started in the second half of 1936. The Turano dam was finished in 1938, while the Salto dam in 1939. The Salto reservoir, after a water transfer from Turano reservoir by an underground tunnel, is connected to the Cotilia hydroelectric plant by a pipeline about $12 \mathrm{~km}$ long (Fig. 3).

In 1940 , the realization of the pumping station at the Ripasottile Lake started (Fig. 4). It artificially conveys waters from the low lands (about $40 \mathrm{~km}^{2}$ ) in the right bank of the Velino River.

From the second postwar period to the 1980s, many minor works were realized: (i) many kilometers of rural roads; (ii) more than $60 \mathrm{~km}$ of downstream water draining canals; (iii) the main derivation and irrigation canals in many areas of the Plain; (iv) Velino River barrage dam in order to draw 4,500 $1 / \mathrm{s}$ for irrigation purpose. More recently, the irrigation plant at Camporeatino and Porrara (Rieti vegetable garden; $2.5 \mathrm{~km}^{2}$ in size) and the test irrigation plant at Pratolungo were realized.

Only at the end of 1900s all the main reclamation works were accomplished. As a whole, the works completed for the Rieti Plain irrigation network have cost more than 15.5 million euros.

The Velino River and its main tributaries like the Salto and Turano rivers, the La Riana Creek and the Canera Torrent, constitute the draining network in the Consortium area; the S. Susanna, Monticchiolo Reopasto and Maraone Caneretta artificial connection canals play an important hydraulic role as well. Marsh waters collected by the reclamation canals were in the past drained from the Lungo Lake through the S. Susanna River to the Ripasottile Lake and then through the Fiumarone to the Velino River. At present, the Ripasottile Lake waters are directly pumped to the Velino River, thus maintaining the lakes hydrostatic level $2 \mathrm{~m}$ below the natural level (from 371 to $369 \mathrm{~m}$ ), lowering down the water table to dry most of the marshy area around the lakes and preventing this area from overflows during the Velino floods. Therefore, the Fogliano Lake, just to the south of Lungo Lake, is now quite completely dried, buried and covered by dense reed vegetation.

The features of the watercourses in the Consortium area depend on pedology, slope and land-use. They have seasonal flow regime, are often impetuous streams at higher elevations and calm streams within the plain. 

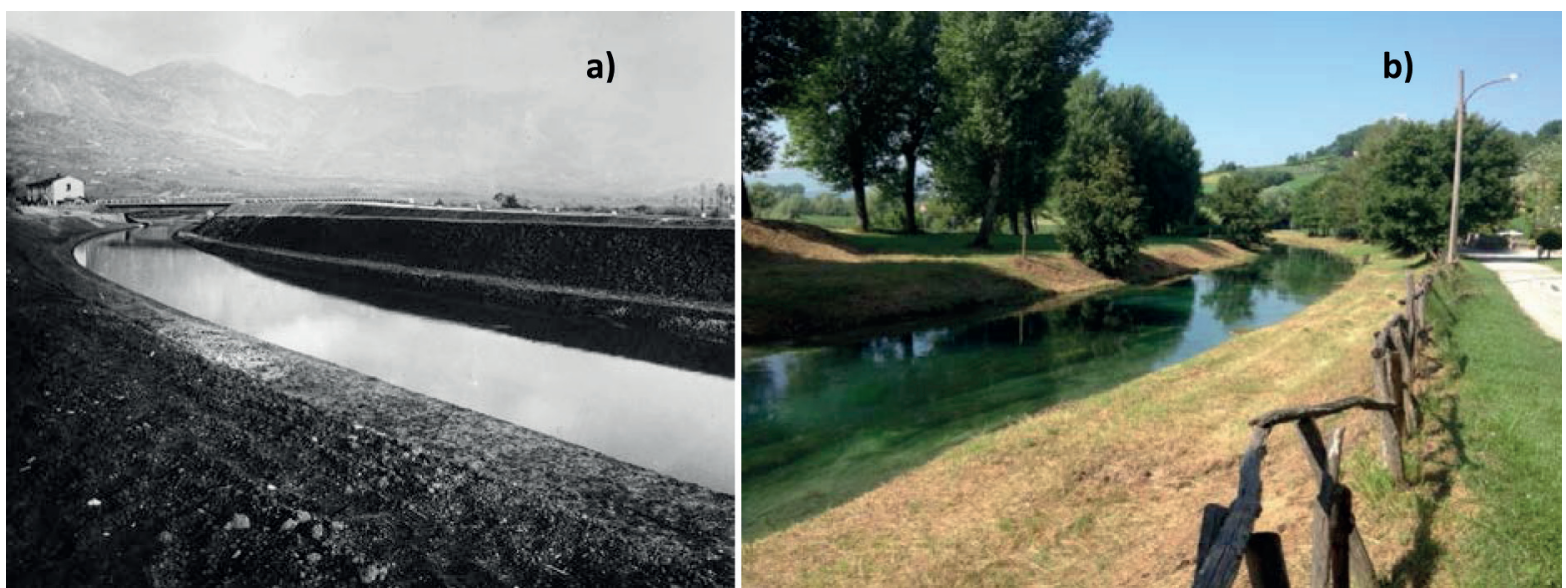

Fig. 2 - The S. Susanna Canal: a) just after the realization (end of 1930s; from Land Reclamation Authority collection); b) nowadays.

Fig. 2 - Il Canale di S. Susanna: a) appena dopo la sua realizzazione (fine anni 1930; dall'archivio del Consorzio di Bonifica); b) come appare attualmente.

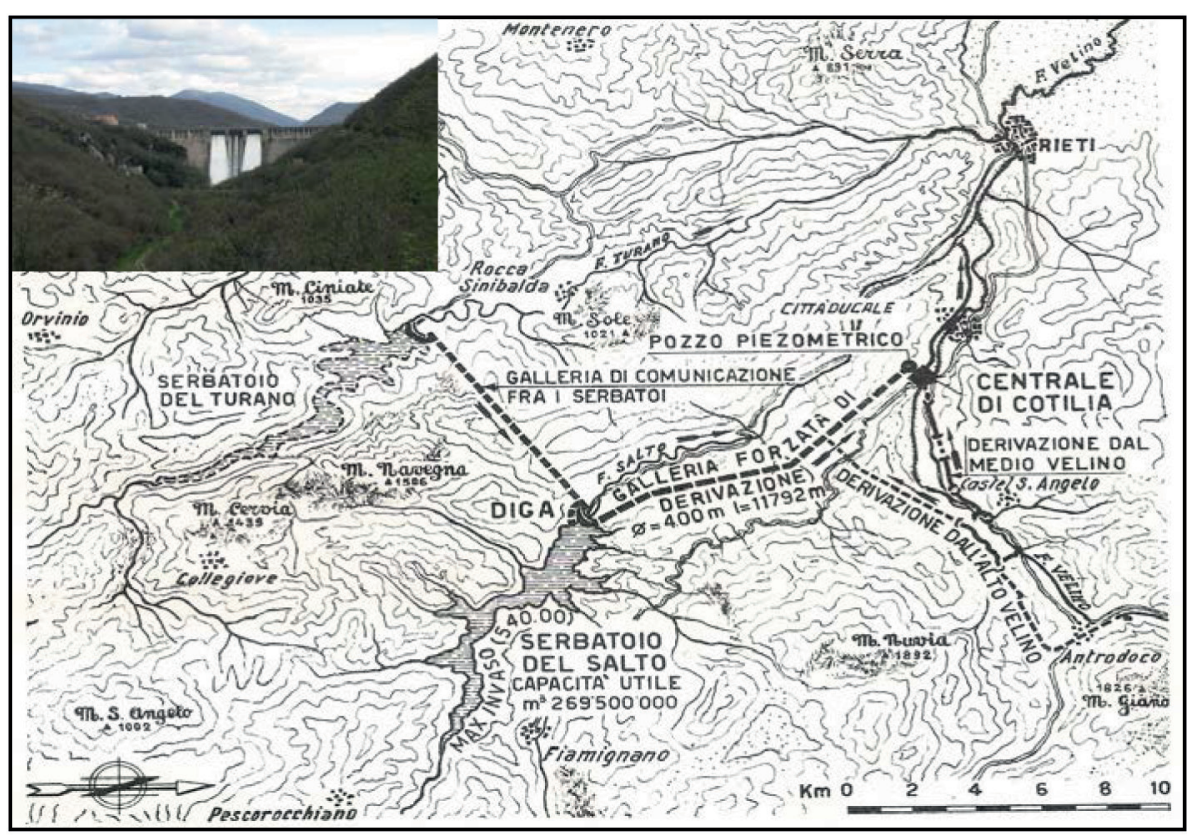

Fig. 3 - Sketch map of the Salto and Turano reservoirs (Velino River Basin; from ANIDEL 1952). Upper left, the Turano dam.

Fig. 3 - Schema dei bacini del Salto e del Turano (bacino idrografico del Fiume Velino; da ANIDEL 1952). In alto a sinistra, la diga del Turano.

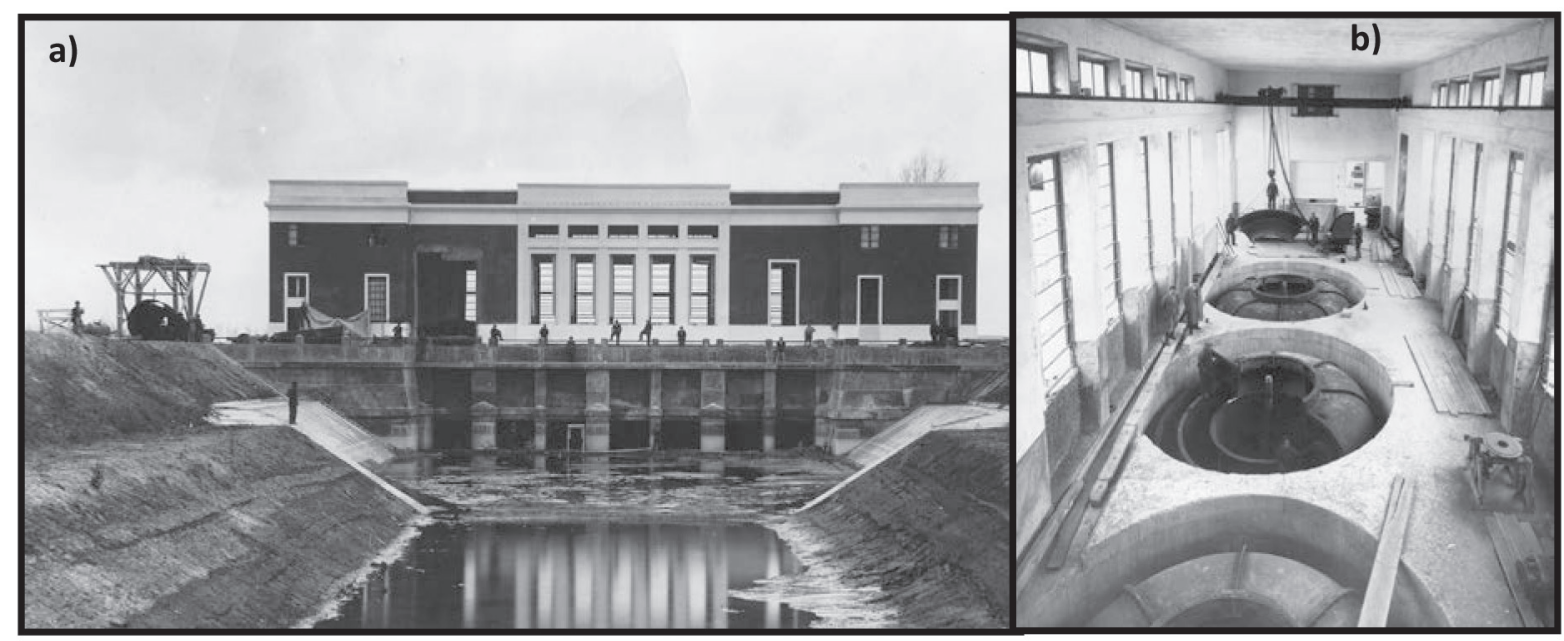

Fig. 4 - The Ripasottile Lake pumping plant (from Land Reclamation Authority collection): a) under construction (1940); b) installation of the pumps.

Fig. 4 - L'impianto idrovoro del Lago di Ripasottile (dall'archivio del Consorzio di Bonifica): a) in costruzione (1940); b) installazione delle idrovore. 
The Consortium activity is aimed to maintain the efficiency of the draining network, preventing flood of meteoric waters and major erosion or landslide processes. The main criteria adopted for the realization of maintenance works regard: (i) assignment of priority to high hydraulic, hydrogeological and degradation hazard zone; (ii) flood process analyses; (iii) preferential localization of actions in the upstream sectors, which favors benefits also in the downstream sectors (e.g., less erosion and filling of the canals) especially using environmentally sustainable methods; (iv) resource distribution throughout all the managed territory.

\section{Results and Discusion The Rieti plain irrigation management}

The irrigation plan of the Consortium territory started with a preliminary project dated 1946, opportunely modified and integrated with time and the irrigation network realization is instead still in progress although under completion. The Consortium irrigation activities in the Rieti Plain date back to 1953 and in 1960 started the realization of the upstream connection canal in the left bank of the Velino River (length $7.5 \mathrm{~km}$; width $18 \mathrm{~m}$; max discharge $16 \mathrm{~m}^{3} / \mathrm{s}$ ), accomplished in 1966, which conveys waters from the W sector of the reclamation district. In 1993 the pumping station at Reopasto/Pantano, along the Maraone Canal, started to take away waters from the Rieti Plain low lands in the left bank of the Velino River ( $\mathrm{N}$ of Terria Village, about $15 \mathrm{~km}^{2}$ in size) also for contrasting flood events from the Velino River.

The present irrigation service activities refer to the Rieti Land Reclamation Authority irrigation scheme (Iacuitto 2011) here briefly described. Water supply is granted by a Water Derivation Concession (D.M.LL.PP. dated 24/04/1952 N.3835) of $5 \mathrm{~m}^{3} / \mathrm{s}$ from the Velino River. The water concession is distributed between a first drawing of $490 \mathrm{l} / \mathrm{s}$ from the pumping station at Ponte Cavallotti and a second one of 4510 1/s from a barrage dam at Voto dei Santi (Fig. 5), both in the Rieti Plain territory (Fig. 1).

The first derivation consists in water uplift (14 m prevalence) by four pumps. Water is distributed by concrete waterways to Porrara-Padule (70 1/s and $2.67 \mathrm{l} / \mathrm{s} \cdot \mathrm{ha}$ ) and Camporeatino/ S. Eleuterio (210 l/s and $1.00 \mathrm{l} / \mathrm{s} \cdot \mathrm{ha}, 240 \mathrm{l} / \mathrm{s}$ and $1.91 \mathrm{l} / \mathrm{s} \cdot \mathrm{ha}$, respectively) districts (Fig. 1) by direct flowing based on assigned supplying turns.

The Voto dei Santi derivation is distributed by gravity to a right $(3150 \mathrm{l} / \mathrm{s})$ and a left $(1360 \mathrm{l} / \mathrm{s})$ diversion chambers. The first one feeds two irrigation ditches supplying 1940 and 1210 l/s to the Chiesa Nuova-Saletto and the Basso Cottano districts (Fig. 1), respectively.

A portion of $36 \mathrm{l} / \mathrm{s}$ and about $0.75 \mathrm{l} / \mathrm{s} \cdot \mathrm{ha}$ of Basso Cottano waters are derived by electric pumps in the test irrigation plant of Pratolungo (W to the Rieti Town; water distribution on 48 ha by hydrants controlled by computer on the basis of assigned turns).

The left diversion chamber feeds two ditches supplying 830 and $530 \mathrm{l} / \mathrm{s}$ to the Comunali and the Sinistra Turano districts (Fig. 1), respectively.

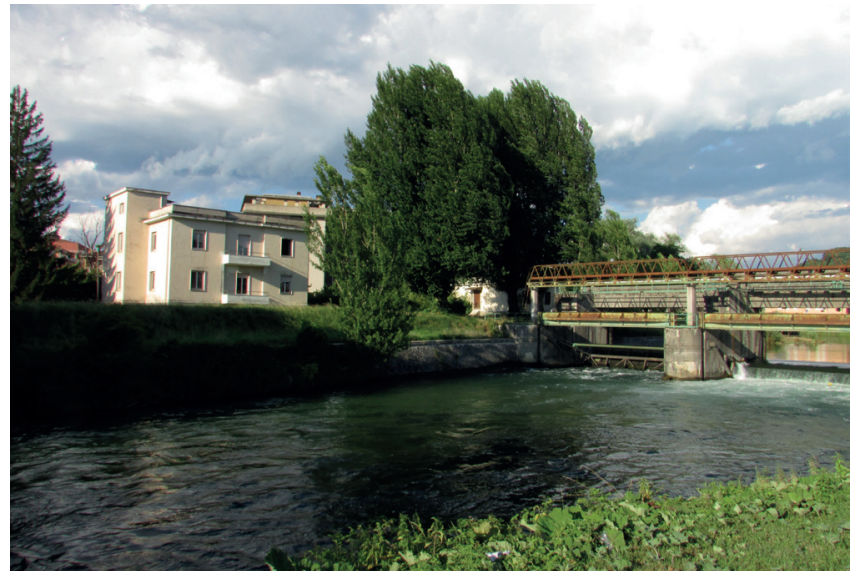

Fig. 5 - The barrage dam for water derivation and distribution at Voto dei Santi. The building at left (right bank of Velino River) is the Consortium for Rieti Land Reclamation headquarter (from Land Reclamation Authority collection).

Fig. 5 - Traversa fluviale per la derivazione e distribuzione idrica in località Voto dei Santi. Il palazzo a sinistra (sponda destra del Fiume Velino) è la sede del Consorzio della Bonifica Reatina (dall'archivio del Consorzio di Bonifica).

Two minor derivations are in Montisola (30 l/s for $100 \mathrm{ha}$ ), $\mathrm{N}$ sector of Velino River, and in Casette districts (15 1/s for 20 ha), S sector of Salto River.

Examples of concrete irrigation canals and drip irrigation systems are shown in Figs. 6 and 7, respectively.

From the physical-chemical viewpoint, the Rieti Plain soils show a fair-good attitude to irrigated agriculture. In addition, regarding fertility, soils: (i) are never very poor; (ii) $62 \%$ are average (but may be improved by fertilization); (iii) $28 \%$ are averagely productive; (iv) $10 \%$ are rich.

Furthermore, irrigation attitude is improved by groundwater quality, since water chemical characteristics are inconsistent with alkalinization problems (SAR values, sodium adsorption ratio, are 1.4-1.8; other salt contents are $<1.5 \mathrm{~g} / \mathrm{l}$, i.e. under the saline tolerance threshold; Tab. 2). In agreement with a good agricultural attitude of the Plain is also the good quality of the irrigation water drawn from Velino River.

\section{Protection of the Plain attained through the integrated management}

The Consortium actively works for hydraulic protection in order to guarantee the best safety from flood risks throughout the whole Consortium territory and, at this aim, it daily attends ordinary maintenance services and extraordinary works on the water courses, including the minor stream network. The rules about hydraulic management and land protection issued in the last years led to the adoption of the Management Plan for Flood Risk in Central Apennine Hydrographical District (PGRAAC; art.6 - D.Lgs 49/2010, in compliance to the 2007/60/CE Directive) by the Tiber River Basin Authority (Autorità di Bacino del Fiume Tevere 2015). The Plan assigned (Fig. 8) the Rieti Plain to a risk class from R2 (intermediate) to R1 (null) and the residential areas to a class R4 (very high).

The built of the dams along the Salto and Turano River was realized also to protect the Rieti Plain and the Rieti Town 


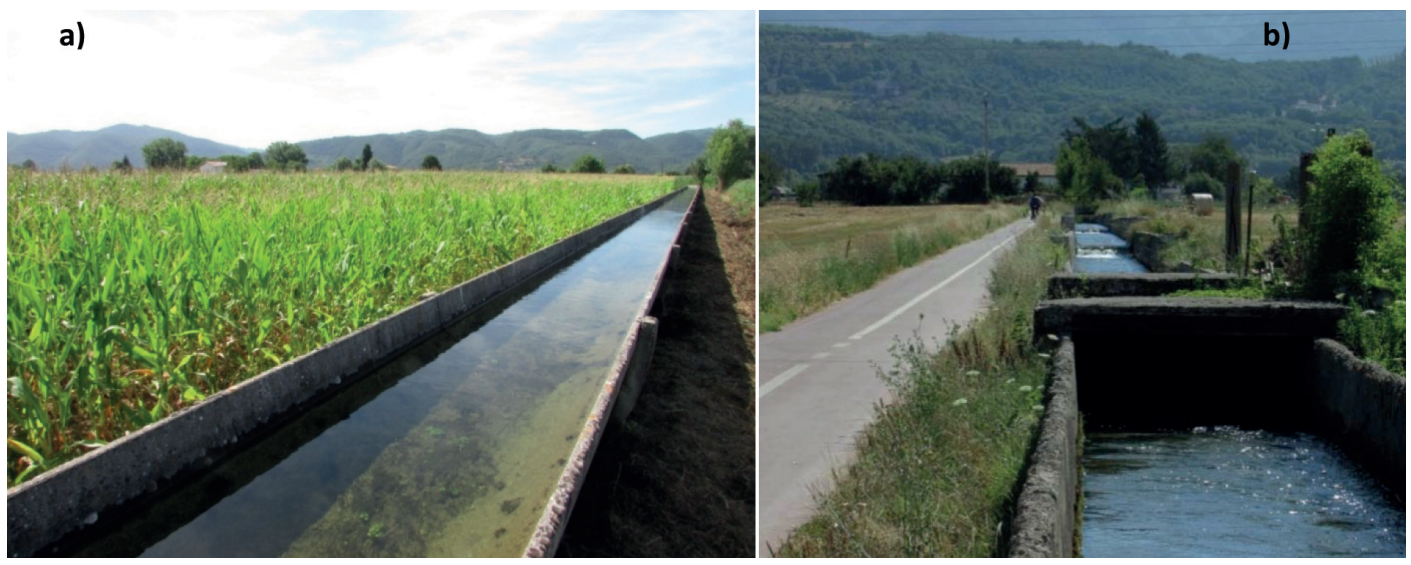

Fig. $6(a, b)$ - Concrete irrigation canals for corn $\mathrm{cul}$ tivation (from Land Reclamation Authority collection).

Fig. 6 (a, b) - Canali di irrigazione in cemento per la coltivazione del mais (dall'archivio del Consorzio di Bonifica).
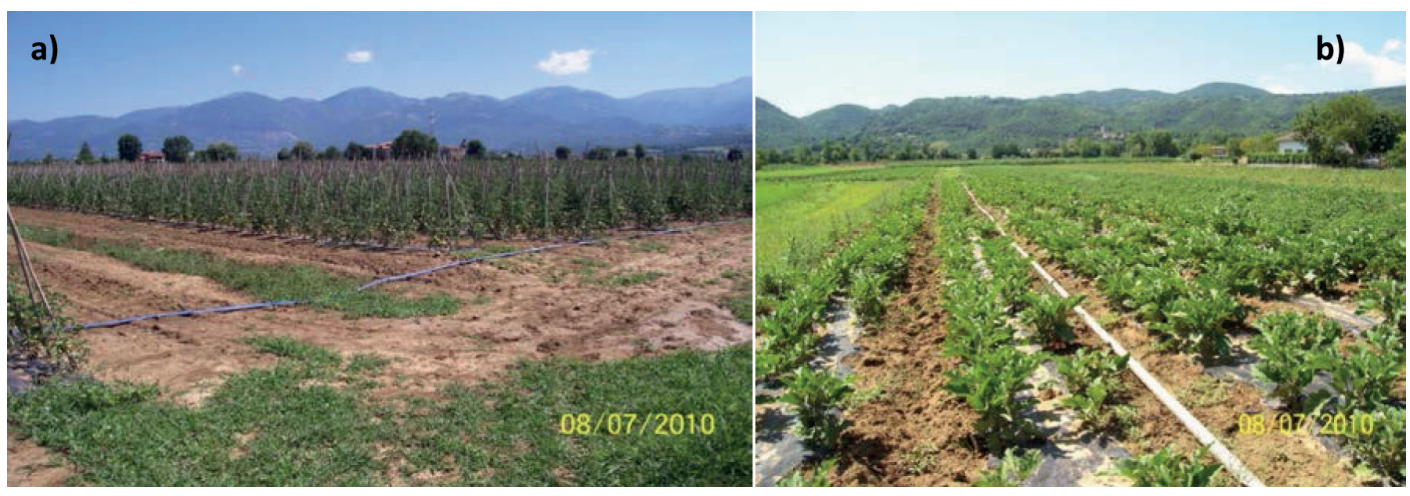

Fig. $7(a, b)$ - Drip irrigation systems for vegetable cultivation (from Land Reclamation Authority collection).

Fig. 7 (a, b) - Sistemi di irrigazione a goccia per le colture ortive (dall'archivio del Consorzio di Bonifica).

Tab. 2 - Groundwater chemical analyses (AGROTEC 1979)

Tab. 2 - Analisi chimiche delle acque sotterranee (AGROTEC 1979).

\begin{tabular}{|c|c|c|c|c|c|c|c|c|}
\hline Sample & $\mathrm{pH}$ & $\begin{array}{c}\text { ECw } \\
\left(\mu \mathrm{S} / \mathrm{cm}, 25^{\circ} \mathrm{C}\right)\end{array}$ & TDS (\%o) & $\underset{(\mathrm{meq} / \mathrm{l})}{\mathrm{Na}}$ & $\underset{(\mathrm{meq} / \mathrm{l})}{\mathrm{Ca}}$ & $\underset{(\mathrm{meq} / \mathrm{l})}{\mathrm{Mg}}$ & $\begin{array}{c}\mathrm{K} \\
(\mathrm{meq} / \mathrm{l})\end{array}$ & SAR \\
\hline 1 & 6.65 & 764 & 0.49 & 3.1 & 8.0 & 1.3 & 0.1 & 1.4 \\
\hline 5 & 6.70 & 896 & 0.57 & 3.3 & 9.8 & 0.3 & 0.2 & 1.5 \\
\hline 7 & 6.50 & 345 & 0.22 & 3.2 & 6.4 & 1.5 & 0.1 & 1.6 \\
\hline 9 & 6.65 & 819 & 0.52 & 3.9 & 10.0 & 0.2 & 0.2 & 1.7 \\
\hline 13 & 6.60 & 509 & 0.33 & 3.8 & 7.3 & 1.5 & 0.1 & 1.8 \\
\hline
\end{tabular}

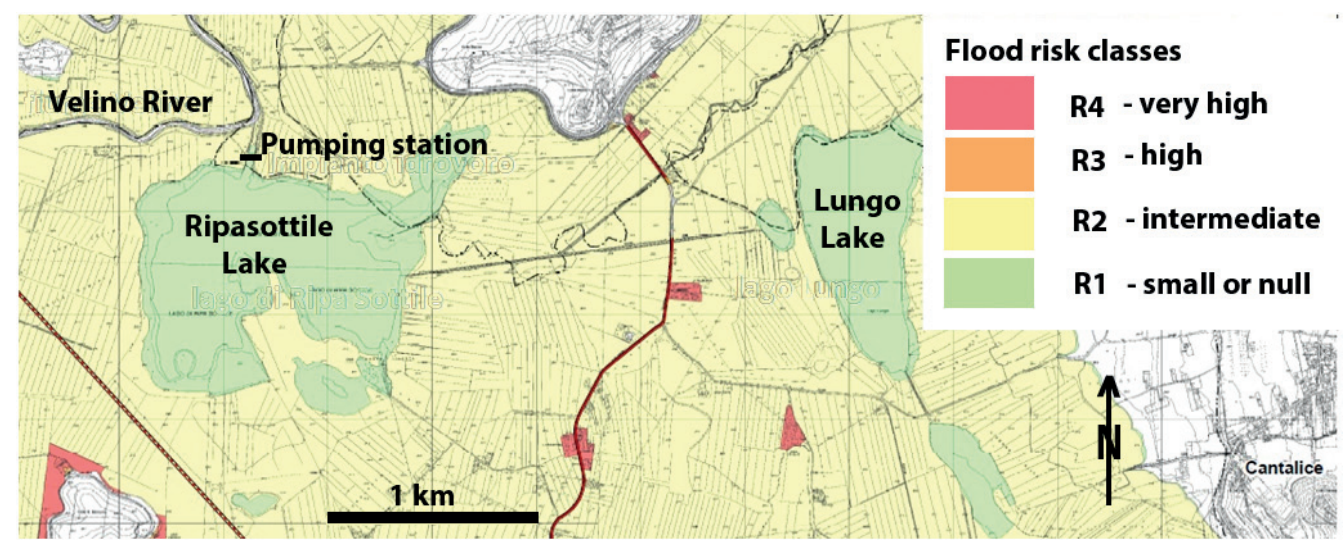

Fig. 8 - Map detail of the management plan for flood risk in Rieti Plain area (from Autorità di Bacino del Fiume Tevere 2015).

Fig. 8 - Mappa di dettaglio del Piano di Gestione del rischio di alluvione nell'area della Piana Reatina (da Autorità di Bacino del Fiume Tevere 2015). 
from floods, but from the beginning of the hydroelectric plant activity, profits from electric power production became the main goal. In the postwar period Lodovico Spada Potenziani, President of the Farmer Confederation at that time, highlighted that the inappropriate management of hydroelectric reservoir waters was the cause of relevant floods in the Rieti Town. The meteoclimatic data analyses (Centro Appenninico del Terminillo "Carlo Jucci" 2011) evidence that the flood events are not strictly correlated with the monthly and/or annual rainfall peaks, but are related to the hydraulic procedures for the water level control in the Salto and Turano artificial reservoirs. With damage compensation obtained from Terni Company, the Reclamation Consortium was able to start the works for flood protection and irrigation network in all the Rieti Plain.

Flood events in the Rieti Plain and in the low districts of Rieti Town often occurred with time (e.g., Genio Civile di Rieti 1937; GNDCI-CNR 1994; ARDIS 2011; Marinelli and Menotti 2014; Fig. 9), but nowadays they show less intensity than in the past. The most relevant events after the flood protection action works are as follows: $18^{\text {th }}$ December 1952 , July $1954,8^{\text {th }}$ December $1959,16^{\text {th }}$ February 1976, $23^{\text {rd }}$ December $1982,8^{\text {th }}$ December $1992,18^{\text {th }}$ November $1996,6^{\text {th }}$ October1998, 15 ${ }^{\text {th }}$ December 1999 and $2^{\text {nd }}$ December 2010.

\section{Conclusions}

The Consortium for Rieti Land Reclamation (Latium, Central Italy) is mainly placed in the Rieti Plain, which represents an intra-Apennine basin (Plio-Quaternary alluvial and fluvial-lacustrine sediments) bordered by reliefs (calcareous-marly and detritic deposits) with huge amounts of water resources. The hydrogeological asset of the Rieti Plain is reliant on the regional hydrodynamics; major springs fed by the basal calcareous aquifer occur in it. A phreatic groundwater body having hydraulic exchanges variable in time and space with streamwater is hosted in the Plain (depth to groundwater 1-4 m; groundwater flow directions generally from SSE to NNW). A relatively scarce effective infiltration (about $200 \mathrm{~mm} / \mathrm{a}, 0.6 \mathrm{~m}^{3} / \mathrm{s}$ ) was estimated.

The Rieti Land Reclamation Authority is charged to realize the Reclamation General Project by the finalization of hydraulic actions aimed at irrigation and prevention of ordinary and extraordinary floods in the Rieti Plain. These actions mainly have consisted in: (i) realization of the Salto and Turano artificial reservoirs; (ii) increasing of the Velino River discharge to the Marmore Falls; (iii) realization of two upstream connection canals in both right and left bank of Velino River; (iv) arrangement of Maraone Creek and Vergara Canal; (v) realization of two pumping stations at Ripasottile and Reopasto; (vi) forestry-hydraulic and hydrogeological protection works.

The Velino River and its main tributaries constitute the draining network in the Consortium area; artificial connection canals have as well a main hydraulic role. The Consortium activity is aimed at the preservation of the efficiency of this network and preventing floods, major erosion or landslide processes, mainly by maintenance of stream shape and efficiency of hydraulic works according to a service program detailed in typology and time. The main actions consist in stream cleaning, vegetation cutting and localized works.

The Consortium manages at present all hydraulic works of regional relevance (pumping stations and connection canals), public service works (torrents and creeks) and service for the consortium members (reclamation and irrigation canals). The Consortium daily attends ordinary maintenance services and extraordinary works on the watercourse network. The Rieti Plain was assigned to risk classes from R2 (intermediate) to R1 (null) and the residential areas to R4 (very high). Flood events in the Rieti Plain often occurred with time, but nowadays they show less intensity than in the past.

The Salto and Turano dams were realized also to protect the Rieti Plain and the Rieti Town from floods, but then profits from electric power production became the main goal. There is evidence that the flood events are not strictly correlated to

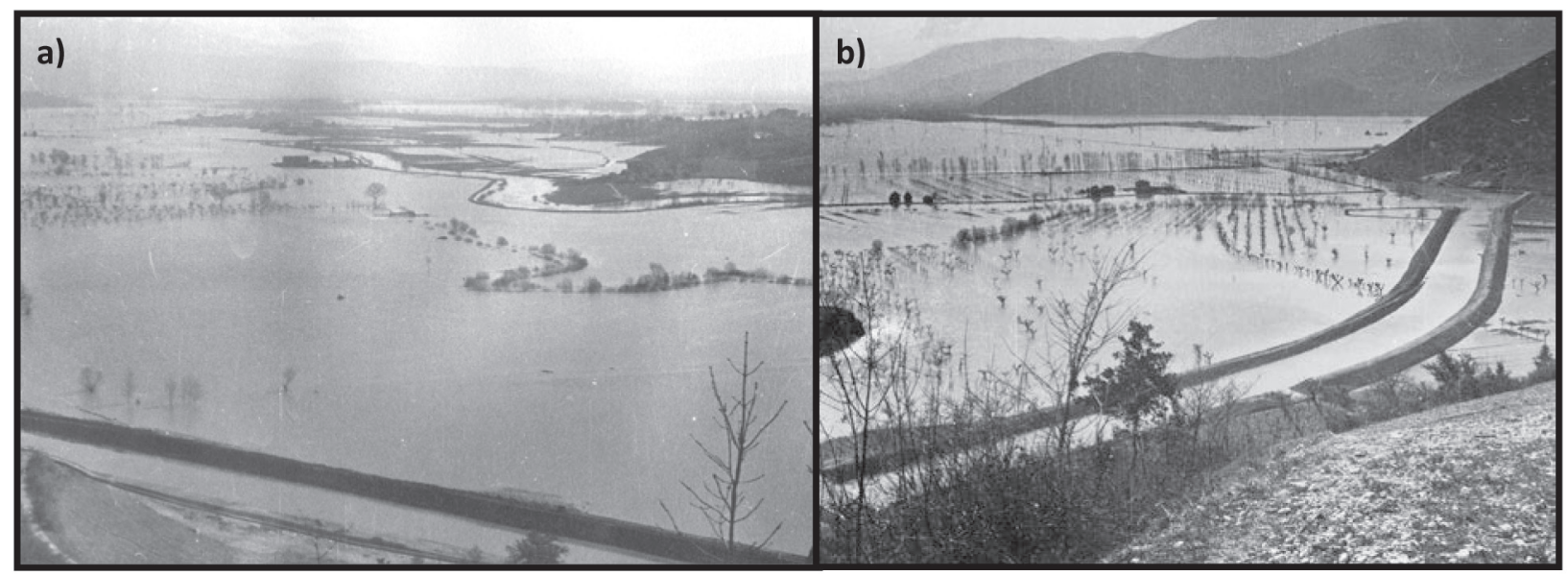

Fig. 9 - Two great floods before the realization of flood protection works in the Rieti Plain: a) 1935; b) 1937-1938. In the second picture, the S. Susanna Canal at the Velino River confluence is evident (e.g., Genio Civile di Rieti 1937; GNDCI-CNR 1994).

Fig. 9 - Foto di due grandi eventi di esondazione prima della realizzazione degli interventi di protezione idraulica nella Piana Reatina: a) 1935 ; b) $1937-1938$. Nella seconda foto è visibile il Canale di S. Susanna alla confluenza con il Fiume Velino (e.g., Genio Civile di Rieti 1937; GNDCI-CNR 1994). 
the rainfall peaks, but to the hydraulic procedures for water level control in the Salto and Turano artificial reservoirs.

The water supply for irrigation of the Consortium territory is from the Velino River $\left(5 \mathrm{~m}^{3} / \mathrm{s}\right)$, distributed between a fist drawing of $490 \mathrm{l} / \mathrm{s}$ from the pumping station at Ponte Cavallotti and a second one of $4510 \mathrm{l} / \mathrm{s}$ from a barrage dam at Voto dei Santi. The latter barrage delivers water by gravity to a right $(3150 \mathrm{l} / \mathrm{s})$ and a left $(1360 \mathrm{l} / \mathrm{s})$ diversion chambers. Water is distributed by concrete irrigation ditches based on assigned turns in order to differentiate the supplied water amounts; a test irrigation plant at Pratolungo allows water distribution by hydrants controlled by computer.

The Rieti Plain soils show a fair-good attitude to irrigated agriculture and their fertility has mainly (62\%) an average degree, which may be improved by fertilization, and for a $10 \%$ attains a rich degree. Furthermore, irrigation attitude is improved by the good quality of the water drawn from Velino River and by groundwater quality, since no soil alkalinization problems are ongoing.

\section{REFERENCES}

AGROTEC (1979) Progetto per l'irrigazione della Piana Reatina. Relazione generale. "The Irrigation Project of the Rieti Plain. General Report". Agrotec S.r.l., Roma.

ANIDEL (1952) Le dighe a ritenuta. Dighe del Gruppo TERNI "The dams of the TERNI GROUP”. vol. VI. Associazione Nazionale Imprese Produttrici e Distributrici di Energia Elettrica. Roma.

Annali Idrologici (1921-2012) Parte prima e Parte seconda (Sezione di Roma) "First and Second Part (Rome Unit)". Servizio Idrografico, Ministero dei Lavori Pubblici / Servizio Idrografico e Mareografico Nazionale, Dipartimento per i Servizi Tecnici Nazionali, Presidenza del Consiglio dei Ministri, Roma.

ARDIS (2011) Relazione tecnica ed Elaborato grafico dei Lavori di messa in sicurezza delle sponde del Fiume Velino nel tratto della Città di Rieti, compreso tra le località "Ponte Cavallotti" e lo sbarramento del Consorzio di Bonifica (Allegato 1 e 2) "Report and Map of the works for the Velino River bank safety, between the sites of Ponte Cavallotti and the Reclamation Authority dam (Annexes 1 and 2)". Coletta V. (ed.), Regione Lazio, Roma.

Autorità di Bacino del Fiume Tevere (2015) Piano di Gestione del Rischio Alluvioni per il Distretto Idrografico dell'Appennino Centrale (PGRAAC) - Direttiva 2007/60/CE - Piana Reatina "Flood risk management plan for the Central Apennine Hydrographycal District - 2007/60/CE Directive - Rieti Plain". Roma, www.abtevere.it, July 2015.

Boni C, Capelli G, Petitta M (1995) Carta idrogeologica dell'alta e media valle del fiume Velino "Hydrogeological map of the high and middle Velino River Valley”. Università di Roma La Sapienza, Università Roma Tre, Comunità Montana del Velino. System Cart, Roma.

Centro Appenninico del Terminillo "Carlo Jucci" (2011) Dati meteorologici "Meteoclimatic data". Centro Appenninico del Terminillo "Carlo Jucci". Università degli Studi di Perugia.

Di Domenicantonio A (2000) La pianificazione del Bacino del Fiume Tevere 1999-2000 "The Tiber River Basin Planning". Autorità di Bacino del Fiume Tevere, anno V, n.12-13, Gangemi Editore.
Falcetti S, Guerrieri L, Marino M, Martarelli L, Menotti R M, Millesimi F, Moretti P, Scalise A R (2015) La città di Rieti e la piana reatina. Lineamenti geologici e idrogeologici, tra storia, archeologia e patrimonio naturalistico "The Rieti Town and the Rieti Plain. Geological and hydrogeological outlines among history, archeology and natural heritage". Atti ISPRA $5^{\circ}$ Congresso Nazionale Geologia e Turismo (poster), Bologna, Giugno 2013. 8: 628-632.

Genio Civile di Rieti (1937) Danni della piena del Velino del 15.12.1937. Rieti. Planimetria scala 1:2000 "Damages after the December $15^{\text {th }}$ 1937 flood event. Rieti. Map at 1:2,000 scale". Archivio di Stato di Rieti, Fondo Archivistico, Inventario n.25, Min.LL.PP., Ufficio del Genio Civile di Rieti, faldone n.99, Rieti.

GNDCI-CNR (1994) Sistema Informativo sulle Catastrofi Idrogeologiche. Catalogo delle informazioni sugli Eventi di Piena "Hydrogeological Disaster Informative System. Flood Event Inventory". PROGETTO AVI, Perugia.

Iacuitto M (2011) Consorzio della Bonifica Reatina "The Rieti Land Reclamation Authority". Convegno "Rieti Caput Aquae", Rieti, Giugno 2011.

Lorenzetti R (1989) Storia sociale e economica della Sabina "Social and economic history of Sabina district". Istituto E. Cirese, Rieti.

Manfredini M (1972) Studio idrogeologico della Piana di Rieti " $H y$ drogeological study of the Rieti Plain". Quad. Ist. Ric. Acque CNR 6: 87-122.

Marinelli R (2010) La Bonifica Reatina "The Rieti Land Reclamation". Ist. Suore Francescane S. Filippa Mareri, Borgo San Pietro di Petrella Salto, Rieti. Ed. Libreria Colacchi, L'Aquila.

Marinelli R, Menotti R M (2014) The risks of flooding in the City of Rieti, the Centre of Italy. Acc. Naz. Lincei. Atti del Convegno: "Resilienza delle città d'arte alle catastrofi idrogeologiche: successi e insuccessi dell'esperienza italiana” (poster), Novembre 2014, Rome (Italy).

Martarelli L, Petitta M, Scalise A R, Silvi A (2008) Cartografia idrogeologica sperimentale della Piana Reatina (Lazio) "Experimental bydrogeological cartography of the Rieti Plain (Latium)". Mem. Descr. Carta Geol. d'It. LXXXI: 137-156.

Acknowledgments: anonymous referees are kindly acknowledged for their useful comments and suggestions. 